\title{
Roles of female leaders of education in Vietnam National University
}

\author{
Nguyen Duc Huy, Nguyen Huu Chung*, Nguyen Trung Kien \\ VNU University of Education, 144 Xuan Thuy, Cau Giay, Hanoi, Vietnam \\ Received 30 November 2017 \\ Revised 15 December 2017; Accepted 25 December 2017
}

\begin{abstract}
In order to understanding the increasing number of women as leaders in Vietnamese higher education. The research was a qualitative study using a narrative inquiry research design as a means to elicit the lived experience of some respected female education leaders in VNU. However, a higher number of male leaders than female ones still fills senior management roles in Vietnamese higher education. This study explores of perspective the leadership styles of women leaders who want to positions of leadership in higher education. Most all of the female leaders have not leadership training at any school, so their leadership and management by experiences. The identification of important factors effect on the educational leadership of these figures will provide insight into the nature of leadership in relation to teaching and learning in Vietnamese higher education. Research will focus on interview as method for exploring thestories offemale educational leaders in Vietnam National University, Hanoi (VNU). The role of female leaders in changing, developing and perfecting valuable structures. Exploring these stories will demonstrate and can be understood the leadership styles of female leader in at VNU.
\end{abstract}

Keywords: leadership; female education leader; highereducation.

\section{Introduction}

The goal of Vietnam is to become an industrialized and modernized country by 2020 . In order to achieve this goal,Vietnamese highereducation has changed in responseto a varietyof educational, political, economic and structural challenges. The national education system of Vietnam includes 4 levels of education and training in the national education system of Vietnam: pre-school education, general education, professional education and higher education. Higher education includes education at college, university, masters and doctoral levels [1].

VNU is the largest comprehensive higher education and research center in Vietnam. The number of teacher and education manager at all levels has been increasing rapidly with

\footnotetext{
${ }^{*}$ Corresponding author. Tel.: 84-24-73017123.

Email: chungnh@vnu.edu.vn

https://doi.org/10.25073/2588-1159/vnuer.4117
}

improved qualifications. By the end of 2015 in the whole VNU there were 51 professors, 336 associate professors and $881 \mathrm{PhDs}$. The number university increasing from 3 in 1993 to 6 in 2017. The number of teachers and education manager attaining standard and higher level of education has been increasing. The quality of education at all levels has improved [2].

Several recent studies in the abroad haveset out to examine and analysestheleadership styles of women leaders in highereducation in orderto betterunderstandand informmodels for women whoaspiretopositions ofleadership in highereducation. Allan, Gordon and Iverson note the image of the autonomous, solo leader persists in U.S. higher education. This requires a great amount of interpersonal skill and a temperament that is willing to work with others[3]. Eddyand VanderLinden in theirstudyofcommunitycollegeadministrators self-reports oftheirleadership, found that few differences existed in how men and women 
defined theirleadership[4]. Sanchez Moreno found that women are flexible and adaptive leaders' style in terms of their leadership style.

Therearean increasingnumberof women leadersin VNU highereducation. However, afarhigherproportion ofmales than females stillfillthese roles. Thus we are going to research the roles of female leaders of educational in VNU, Hanoi.

\section{Educational system of Vietnam}

The educational system of Viet Nam includes regular and continuing education. There are 4 levels of education and training in the National Educational System of Viet Nam. Pre-school education for children from 3 months to 6 years old; General education consists of primary, lower secondary and upper secondary education; Professional education includes secondary professional education and vocational education; Higher education includes education at college, university, master's and doctoral levels.

Normally, College education takes 2 to 3 years, University education takes 4 to 6 years, master level takes 1 to 2 years, doctoral level takes 3 to 4 years. The number of teachers and education managers at all levels has been increasing rapidly with improved qualifications. The number of college teachers increased by 3.1 times and that of university teachers by 1.9 times. By 2010, $100 \%$ of teachers at professional education colleges have university or higher qualifications, of which $12 \%$ have Master's degrees and $16.8 \%$ have $\mathrm{PhD}$ degrees $44 \%$ of tertiary education teachers have Master's degrees and $14.4 \%$ have $\mathrm{PhD}$ degrees. The number of lecturers national wide rose from 32,205 in the year 2002 to 84,109 in the year 2012. The quality of the teaching staff has slightly improved $[1,8]$.

\section{Aims of the study}

The aim of this study is exploring the stories of respected female educational leaders in VNU. Exploringthesestories will demonstratethelenses throughwhich leadership and leadership styles canbe understood and negotiated. The identification of significant factors impacting on the educational leadership of these figures has generated theory in relation to the nature of leadership, particularly female leadership, in relation to teaching and learning in VNU.

This will inform decision making and practice by identifying ways that both current and potential educational leaders in VNU might develop their own leadership visions, styles and practices. Such knowledgewill also improvethequalityofprofessional development foreducational leaders in VNUeducation generally. The timeliness of this study is attested to by the recent attention again being given to the number of women in senior positions in Vietnamese universities

\section{Methodology}

\subsection{Research approach and design}

Narrative research was used in this qualitative study as a means to uncover the lived experience of some respected female educational leaders in VNUeducation. The approach adopted forthis studyconceptualism narrativeresearchas ameans to understandmore about individual social change.

Languageis ourmost powerful tool fororganizing experience, and indeed, for constitutingrealities. Byrecountingtheir experience, peoplemakesenseoftheirexperiences and areableto communicatethe ambiguityand complexityofsituations as well theirown complexand unpredictable influences and intentions. As her observes thenarrative approachreveals theuniquestoryofaperson in context[6]. The life experience that infuse the data constitute the primary topic, the true narrative there are assumed to be individual, internal representation of phenomena events, thoughts and feeling to which narrative gives expression [7].

\section{Interview}

The female educational leaders who have been recognized for their contribution to teaching and learning in higher education. Thus, for the purpose of this study, interviewing is an appropriate technique for the research 
issue, and elite interviewing an appropriate subset of interviews as a research tool.

The views of an eliteinterview as onein which anyintervieweeisgiven special, nonstandardized treatment that stresses theinterviewee's definition ofthesituation, encourages the intervieweeto structurethe account and allows theintervieweeintroduceto a considerableextent theirown notions of what is relevant ratherthan relying upon the researcher's notions ofrelevance. Focused interview so that the intervieweecan stress his orher definition of, structure, and relevant data related to asituation. The interviewing system for female leaders in VNU based on the questionairesin Table 1.

\section{Table 1. The Questionaire used for female leaders Interviewing}

\begin{tabular}{|c|c|}
\hline Number & Questions \\
\hline 1 & $\begin{array}{l}\text { What,inyourexperience, isthedistinction, ifany,betweenleadershipand } \\
\text { teachingandlearninginhighereducation? }\end{array}$ \\
\hline 2 & $\begin{array}{l}\text { What havebeen,overall, yourmaindefiningaimsasaleader of teaching andlearninginhigher } \\
\text { education? }\end{array}$ \\
\hline 3 & $\begin{array}{l}\text { Havingoutlined theseaims, whathavebeentheoverall values that have been mostimportant } \\
\text { toyouasaneducational leader? }\end{array}$ \\
\hline 4 & $\begin{array}{l}\text { Haveyourvaluesaboutbeinganeducational leaderchangedduringyour career? } \\
\text { Duringyour career, have therebeenanyparticularincidentsor situations that causedyou }\end{array}$ \\
\hline 5 & $\begin{array}{l}\text { tochangeyourviewsaboutleadershipofteachingand learninginhighereducation? } \\
\text { How wouldyoudescribeyourleadershipstyle? Isthereaparticular metaphororcomparisonthat } \\
\text { youwoulduse todescribeyourvisionofyour roleasa leader ofteachingandlearning? Doyou }\end{array}$ \\
\hline 6 & $\begin{array}{l}\text { thinkotherssharethis view, orarethereevidence that theyseeyoudifferently? } \\
\text { Doyou thinkleadershiprolesanddutiesshouldonlyreallyresideat thetop of an institution,or should }\end{array}$ \\
\hline 7 & $\begin{array}{l}\text { thesebedistributedthroughout theorganization } \\
\text { differentpeopleandinsystemsthatflowthroughtheinstitution? }\end{array}$ \\
\hline 8 & $\begin{array}{l}\text { What hasbeenyourvisionofthemissionandpurposeofyourorganizationin } \\
\text { relationtoteachingandlearning? }\end{array}$ \\
\hline 9 & $\begin{array}{l}\text { Towhatextentdoyoufeel } \\
\text { organizationinteachingandlearninghasbeenachieved? }\end{array}$ \\
\hline 10 & $\begin{array}{l}\text { What havebeenfive thingsthathavemost helpedyou toachievesuccessin teachingand } \\
\text { learninginyourinstitution? }\end{array}$ \\
\hline 11 & $\begin{array}{l}\text { What havebeenfive } \\
\text { andlearninginyourinstitution? }\end{array}$ \\
\hline 12 & $\begin{array}{l}\text { What,inyourview, are the most critical 'drivers'ofachievement inteaching andlearninginhigher } \\
\text { education today? }\end{array}$ \\
\hline 13 & $\begin{array}{l}\text { Inthefuture, whatdoyou thinkwill be thefivemostimportant thingsfora leaderinhigher education } \\
\text { todotoensureachievement andsuccess in teachingand learningintheirinstitution? }\end{array}$ \\
\hline 14 & $\begin{array}{l}\text { What doyou thinkaresomeof themostchallengingissuesleadersof teachingand learning tend } \\
\text { tofaceduring their careers? Howwouldyou } \\
\text { futureleadersineducationshouldbetrainedtocopewith these? }\end{array}$ \\
\hline 15 & $\begin{array}{l}\text { Isthereanythingelseyouwouldlike tonoteforleadersof teachingand learninginhighereducationin } \\
\text { thefuture? Or anyotherparticular pointyou wish tonoteabout thiscasestudy? }\end{array}$ \\
\hline
\end{tabular}

developed and based on an interview schedule. Questions related to personality, developmental characteristics or how participants grew up to

\subsection{Data collection}

The primary method of collecting data was by elite interviews. The interview schedule was be leaders included in the schedule: "You are from a science discipline background. Tell me 
how you came to be a rector, director of member universities and school". The significance of this background to the participant in explaining who theywere and how they got to bein theirpositions could not beignored. Prior to the interviews, biographical data was gleaned and summarized for background information from searches conducted of the web site the VNU universities. Searches were also conducted oflibrarycatalogues and database publications written by participants were read.

\section{Results}

\subsection{Dataanalysisand representation}

The data that has been collected in a way that is both rigorous and scholarly. Theirreview ofseveral approaches to characterizing dataprocessing,analysis and representation indicated threetypical stages:

- Data reduction ordescription pullingtogetherthedatato adescriptive account.

- Datadisplay, classifying or analysis -expandingand extendingthedata beyondadescriptive account.

- Conclusion being made andverification, connecting orinterpretation -the researcheroffers theirinterpretation of what isgoingon.

Theinterviews were mainlyexploratory(about 30 minute). Each interview was conducted, tapedand transcribed in ordertogetas much information. Thetranscripts provided thebasis fordataprocessing, analysisand representation. Theprocess progressed through several consecutive phases: phase 1 transcript verification, phase 2 coding and data reduction, phase 3 profile verification, phase 4 interpreting and drawing conclusions, phase 5 implications and application, phase 6 reflexivity.

A six phase model was used to process, analyses and represent the data:

Phase 1: The tapes were transcribed and transcripts were returned to participants for verification before further work was conducted.

Phase 2: This phase involved numerous readings of each transcript to tease out common themes and points of difference in the interviews. Reduction of the data was done inductively not deductively, that is, I came to the transcripts with an open attitude looking for what emerged as important or of interest from the text.

Phase 3: In this phase, profiles were returned to the participants for verification before further work was conducted. I was particularly concerned to let the participants choose to allow me to include or to request exclusion of some of the material that, in my opinion bordered on the private and personal, but which helped inform the study.

Phase 4: This phase involved offering my interpretation of what has and is going on in the lives of the participants and how this might inform the nature of leadership by women in relation to teaching and learning in VNU.

Phase 5: The primary question that this phase seeks to address is "what does this tell us about the nature of leadership by women in relation to teaching and learning in VNU and what should we be doing about it?"

Phase 6: Thorough preparation, respect and curiosity, being a good listener and flexibility are key attributes for a good interviewer to develop.

Results should be presented here so that key points from interviewee having common and individual.

\subsection{Adviceto female aspirants to} educational leadership

Adviceto female aspirants to educationleadership ranges from thepragmaticdetail to thebroadersystemicissues that aspirants mightface. Former rector of Education University advises femaleaspirants to educational leadership to learn to work systemically and to learn to work thesystem. Recognizingthatleaders need broad based evaluation skills. Office and functional departments (VNU) advises aspirants toget astrong grasp of empirical research, depth of experiencein the disciplinaryand facultycontext and to find a chancellor who values teaching and learninghighly. 
The experience of some females educational leaders in VNUeducation has been presented as profiles under the broad themes identified across all interviews: early influences and career trajectory, leadership and management, values, success, barriers and challenges, and finally, advice to female aspirants to leadership. Whenasked her: how she would advise women aspiring to be future leaders in higher education. Shefeels it's a bit of a regret at the end of my career that kind of crap behaviors' still going on but I can see it in the next generation. It's not going to change. So when I was a younger woman, I think I always looked pretty young for my age, and now I'm an older woman, well, I'm a silly old fart who's female as well and so I'm not going to win that one. So I've just learnt to disengage in one way but to get on with the job that I think I want to get on with and I get my acknowledgements from elsewhere. I'm the one who's invited to other universities to speak.

Deputy Head office of postgraduate academic affairs thinks higher education faces a future that is more data driven so we are going to need really good data information. I think monitoring, really careful systematic quantitative monitoring, is going to be very, very important. This logically leads to the need tohave a strong grasp of empirical research ... people need broad based evaluation skills.

Former vice director academic affairs department thinks that in my experience, there is a significant difference between how women view their careers although it may be changing but certainly with my generation of women than men. Men generallyhad a more structured view of where they were going. I know that's a generalization but women tend to be a lot more accidental aboutit and were usually influenced by other things like spouses, and kids and stufflike that.

As with the former director political students' affairs department recognizes that institutional leadership has made a significant difference to her role as well as 'runs scientific and training council in terms of her discipline and faculty experience. She thinks that the institutional leadership at the vice department academic level is significant enough that aspirants to teaching and Learning roles may think twice about progressing up the ladder if the vice department does not highly value teaching and learning.

While former dean of faculty of management science readily finds the question of advice to female aspirants that they need to learn the art of communication at personal and institutional level and there are forms of communication not justlook into their eyes'.You get out there and become a better communicator.I think it's a reality that needs to be acknowledged by those who are leading who will need to bring people in large institutions to a shared sense ofvalue, a shared agreement, a vision and goals and a shared view of what a quality experience of students would be in teaching and learning.

\subsection{The most pertinentlessons}

The data The data from the key themes were mapped to the categories linked to the development of individuals into leaders. Thedifferent environments, opportunities and thelearning that theyexperienceoverthe courseoftheirlives.

The roleofpeersand mentors both in providingasupportive environment and in providingvicarious learningexperiences to participants is evident. So, too, is the high valueof relationships, collegialityandcommunication both in thevaluesystem ofparticipants but also intheir approach to leadership and their adviceto participants. Whilethe participants demonstrated willingness, flexibilityand competencein takinghold of each opportunityforleadership presented to them, there was little evidenceof considerationgiven to theplanningoftheircareers. Theyhad learned both how to work systemicallyand how to work thesystem. Theylearned how to understand and use empirical data,how to chair andrun committees. 


\section{Conclusions}

This research has identified wheresomerespected femalefigures in educational leadership camefrom and what has shaped theirleadership practices and values.

Guidanceand practical advice forpotentialeducational leaders has been derived from this studyas hasguidance and practical advice forothers in the VNUeducation sectorwho can influencethesectorin ways that willallow aspiring femaleleaders to betterforgetheirown pathwaysto makingadifferenceforthose who seek to learn in the universities.

Women stillplayaverysmall part in thesenioruniversityleadership of VNUeducation. Teachingand learningin VNU education is thepoor cousin to research and this has an impact on thesupport for, and interest in, teaching and learningat both theinstitutional and local level. Women in this studyobserved that the marginalization of women was still apparent in VNU education. Femaleaspirants to educational leadership faceanumberof contextual issues and realities. Participants indicated theimportanceofgainingadoctorateand ofhaving depth of experiencein the facultycontext both as academics and leaders. The management skills are articulate communicator, organized, knowledgeable about higher education and leadership skills.

\section{References}

[1] Education in Vietnam in the early year of the $21^{\text {st }}$ century (2013). Vietnam Education Publishing House.

[2] Web Site: www.vnu.edu.vn

[3] Allan, E.J, Gordon, S. P., \& Iverson (2006). The Chronicle of Higher Education. Review of Higher Education, 30(1), 41-68.

[4] Eddy, P.LandVanderLinden, K.E. (2006). Emerging definitions of leadership in higher education: New visons of leadership or same old hero leader. Community College Review, 34(1), 5-26.

[5] Lopez Yanez, J.L., Sanchez Moreno (2008). Women leaders as agents of change in higher education organizations. Gender in Management, 23(2), 86-102.

[6] Bruner, H., Walter, F (2007). Leadership in context: investigating hierarchical impacts on transformational leadership. Leadership \&Organization Development Journal 28(2), 710-726.

[7] Squire, C., Andrews, M.,\&Tamboukou, M. (2008). Doing narrative research (Introduction, pp. 1-21). London. Sage Publications Ltd.

[8] Chung.N.H. Kiên.N.T. (2017). Developing and nurturing creative thinking in primary school in Japan. Nafostes Conference forCreativity Development and Opportunities for Business and Startup ideas. Trường Đại học Giáo dục. ĐHQGHN. 